\title{
Pertumbuhan Tiga Kultivar Padi (Oryza sativa L.) Terhadap Aplikasi Pupuk Bio Cair dan Kondisi Tanah Pertanian Pasca Erupsi Merapi 2010
}

\author{
DWI UMI SISWANTI ${ }^{1}$, DIAH RACHMAWATI ${ }^{2}$ \\ ${ }^{1}$ Fakultas Biologi, Universitas Gadjah Mada \\ J1. Teknika Selatan Sekip Utara Sleman Yogyakarta 55281 \\ email: dwiumi@ugm.ac.id \\ ${ }^{2}$ Fakultas Biologi, Universitas Gadjah Mada \\ Jl. Teknika Selatan Sekip Utara Sleman Yogyakarta 55281 \\ email: diahbudiharjo@gmail.com
}

\begin{abstract}
The eruption of Mount Merapi at the end of 2010, which resulted in the destruction of land and crops are changing wetland into dry land. Sleman which is located south of Mount Merapi became one of the areas that most affected by the eruption of Merapi in 2010. It is necessary to improve the processing of soil physical properties of degraded areas and efforts to restore agricultural soil nutrient. Returning soil nutrients can be cultivated with the addition of organic material or the addition of microbes. The research aims to analyze the growth of three cultivars of rice (Oryza sativa L.) against the application of biofertilizer in paddy fields were affected by the eruption of Merapi in 2010. These three rice cultivars are Situbagendit, Inpari 20 and Ciherang. This research was conducted by applying the biofertilizer as much as 10 liters / ha were given three times during the vegetative phase, ie: 7, 21 and 35 days after planting. The results of this research indicate that the three rice varieties ie: Situbagendit, Ciherang and Inpari 20 have an optimal growth and an increase in soil nutient content in biofertilizer application.
\end{abstract}

Keywords: biofertilizer, degraded land, Merapi eruption, rice

\section{PENDAHULUAN}

Padi merupakan komoditas strategis yang harus ditingkatkan produksinya mengingat padi sebagai bahan makanan pokok penduduk Indonesia serta jumlah penduduk yang semakin meningkat membutuhkan pemenuhan bahan makanan yang meningkat pula. Namun demikian, peningkatan produktivitas tanaman padi menghadapi berbagai kendala. Salah satu hambatan peningkatan produktivitas tanaman padi adalah menurunnya kualitas lahan pertanian yang antara lain disebabkan oleh residu bahan agro-kimia. Pemakaian bahan kimia yang berkepanjangan pada aplikasi pengolahan lahan menyebabkan terjadinya pengerasan lahan pada lapisan atas tanah. Kesuburan lahan menjadi terganggu sehingga tanah tidak mampu mensuplai unsur hara bagi tanaman. Dinas Pertanian, Peternakan dan kehutanan kabupaten Sleman menyebutkan bahwa lahan pertanian di Sleman telah "sakit". Hal ini dibuktikan dengan pemakaian pupuk kimia mencapai $500 \mathrm{~kg}$ untuk tanah seluas satu hektar, sehingga kandungan senyawa organik tanah menipis (Tribunnews.com, 2013).

Pada akhir tahun 2010 terjadi erupsi Gunung Merapi yang mengakibatkan rusaknya lahan dan tanaman pertanian disamping kerugian harta benda dan nyawa (Any dkk, 2010). Merapi tidak hanya memuntahkan abu vulkanik, namun juga banjir lahar dingin pasca erupsinya. Salah satu sungai yang dilewati banjir lahar dingin adalah Sungai Opak. Banjir lahar dingin menyebabkan beberapa irigasi pertanian tidak berfungsi, akibatnya puluhan hektar tanaman padi mengalami penurunan produksi. Akibat lain dari banjir lahar dingin adalah berubahnya lahan sawah menjadi lahan kering yang hanya mengandalkan curah hujan (Tim Redaksi, 2011).

Menurut data Balittanah (2008), lahan yang rusak akibat abu vulkani Merapi di daerah Sleman seluas $2446 \mathrm{Ha}$, meliputi hutan, sawah dan tegalan. Material vulkanik mematikan dan menurunkan jenis flora dan fauna tanah bahkan mematikan cacing tanah 
hingga populasinya 0 ekor $/ \mathrm{m}^{2}$ serta larva dekomposer bahan organik 0 ekor $/ \mathrm{m}^{2}$. Hasil uji tanah yang terkena dampak abu vulkanik Merapi menunjukkan Ruang Pori Total, Pori Aerasi (tanah), air tersedia dan permeabilitas tidak menunjukkan perbedaan yang jelas pada lapisan yang berbeda. Hal ini menunjukkan bahwa abu yang dimuntahkan Merapi berkadar air tinggi sehingga mampu meresap ke dalam lapisan bawah. Pada lapisan bawah tanah, kandungan air yang cukup tinggi dengan permukaan yang keras dan tidak berpori mengakibatkan air tidak dapat mengalami pernguapan. Maka diperlukan pengolahan tanah untuk memperbaiki sifat fisik ini. Pengolahan tanah ini akan sangat efektif bila dilakukan sampai kedalaman lebih dari $30 \mathrm{~cm}$.

Pengolahan tanah secara fisik dilakukan dengan mencangkul atau membalik tanah untuk mmberikan kesempatan tanah melakukan evapotranspirasi. Selain pengolahan fisik lahan, diperlukan usaha pengembalian hara agar optimum kembali untuk bercocok tanam. Pengembalian hara tanah dapat diusahakan dengan penambahan bahan organik atau penambahan mikroba berupa pupuk bio cair. Secara garis besar keuntungan pemberian pupuk organik adalah memperbaiki sifat fisik, kimia dan biologi tanah serta kondisi sosial masyarakat. Menurut Isroi (2009), pupuk organik juga bisa berbahan dasar kompos, kascing, gambut, rumput laut dan guano. Selain berbahan padat, pupuk organik juga berbahan cair, misalnya urin sapi.

Selain pupuk organik, terdapat pupuk hayati atau pupuk bio. Pupuk ini dapat berupa zat padat (granul) atau berbentuk zat cair. Pupuk jenis ini biasa disebut pupuk bio cair. Pupuk bio cair tidak mengandung N, P atau K melainkan mikroorganisme yang memiliki peranan positif bagi tanaman. Kelompok mikroba yang sering digunakan adalah kelompok mikroba yang menambat $\mathrm{N}$ dari udara, mikroba yang melarutkan hara (terutama unsur P dan K), serta mikroba yang merangsang pertumbuhan tanaman (Isroi, 2009). Mikroba tanah yang berperan dalam proses pelarutan mineral-mineral, mengubah senyawa kompleks menjadi bentuk ion maupun garam-garam yang dapat diserap oleh akar. Sebagai contoh unsur fosfor dalam senyawa kompleks batuan akan terlarutkan oleh kelompok pelarut fosfat seingga menjadi tersedia bagi tanaman (Aryantha, 2002).

Manfaat lain yang diberikan oleh mikroba adalah melindungi akar dari hama dan penyakit, menstimulir sistem perakaran agar berkembang sempurna, memacu mitosis jaringan meristem, penawar racun logam berat, bioregulator tanah. Mikroba juga menghasilkan enzim fosfatase dan fitase serta asam organik untuk berinteraksi dengan senyawa fosfat sukar larut ( Saraswati dkk, 2004).

Berbagai senyawa organik yang dihasilkan oleh mikroba dalam proses dekomposisi limbah organik, berperan dalam merangsang pertumbuhan, mempercepat proses pembungaan, mempercepat proses biosintesis senyawa biokimia, menghambat patogen dan meningkatkan produksi senyawa metabolit sekunder (Aryantha dkk, 2002).

Siswanti, dkk (2010) menyatakan bahwa produktivitas padi di lahan tadah hujan Ngawen, Gunung Kidul menunjukkan adanya peningkatan setelah diberikan perlakuan pupuk bio cair. Penelitian ini juga telah mendapatkan dosis pupuk bio cair sebesar 1015 liter/ha sebagai dosis optimum untuk lahan tadah hujan.

Tujuan penelitian ini adalah untuk menganalisis pertumbuhan tiga kultivar tanaman padi (Oryza sativa L.) terhadap aplikasi pupuk bio cair pada lahan sawah yang terimbas erupsi Merapi tahun 2010. Ketiga kultivar padi tersebut adalah Situbagendit, Inpari 20 dan Ciherang.

\section{METODE}

Penelitian ini dilaksanakan di lereng selatang Gunung Merapi, tepatnya di Desa Wukirsari, Cangkringan, Sleman. Lahan penelitian berupa lahan terimbas erupsi Merapi 2010 dan mengalami penurunan tingkat kesuburan setelah erupsi tersebut. Lahan dibagi menjadi tiga blok, masing-masing blok ditanami varietas Situbagendit, Ciherang dan Inpari 20. Ketiga varietas ini adalah varietas yang lazim ditanam oleh petani setempat. Tanaman padi diberikan perlakuan pra tanam 
berupa pemberian pupuk kandang dengan dosis 10 ton/ha dan dilakukan dua kali pembajakan. Aplikasi pupuk bio cair diberikan pada hari ke 7, 21 dan 35 setelah tanam dengan dosis 10 liter/ha. Penanaman padi dilakukan dengan sistem tegel $(25 \mathrm{~cm} \times 25 \mathrm{~cm})$ dengan masing-masing lubang berisi 1 individu. Parameter pertumbuhan yang diukur pada penelitian ini adalah tinggi tanaman,jumlah daun dan jumlah anakan. Sedangkan parameter lingkungan yang diukur adalah $\mathrm{pH}$ tanah, suhu tanah dan intensitas cahaya. Seluruh parameter diukur mulai hari ke-7 setelah tanam sampai umur 6 minggu (masuk fase generatif).

\section{HASIL}

Hasil pengukuran parameter petumbuhan pada ketiga varietas yaitu :

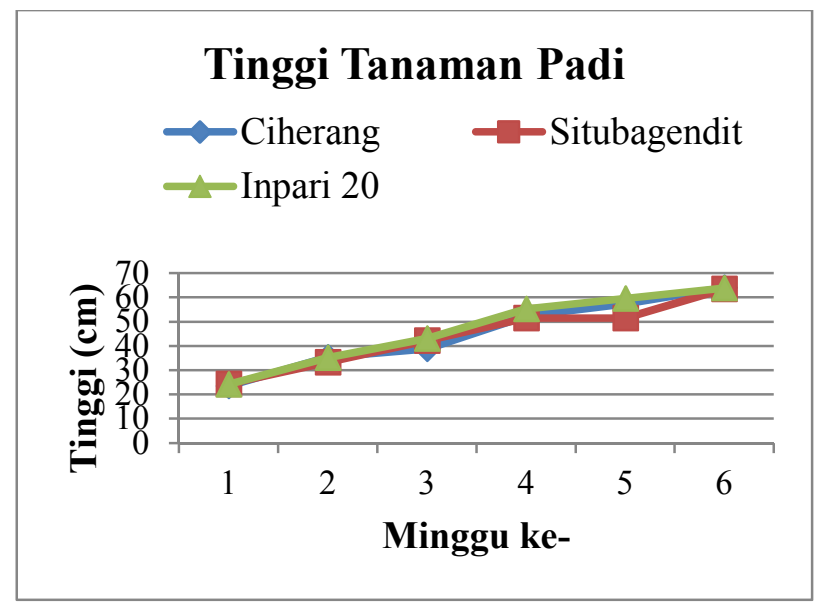

Gambar 1. Tinggi tiga varietas tanaman padi pada 6 minggu pertama setelah tanam

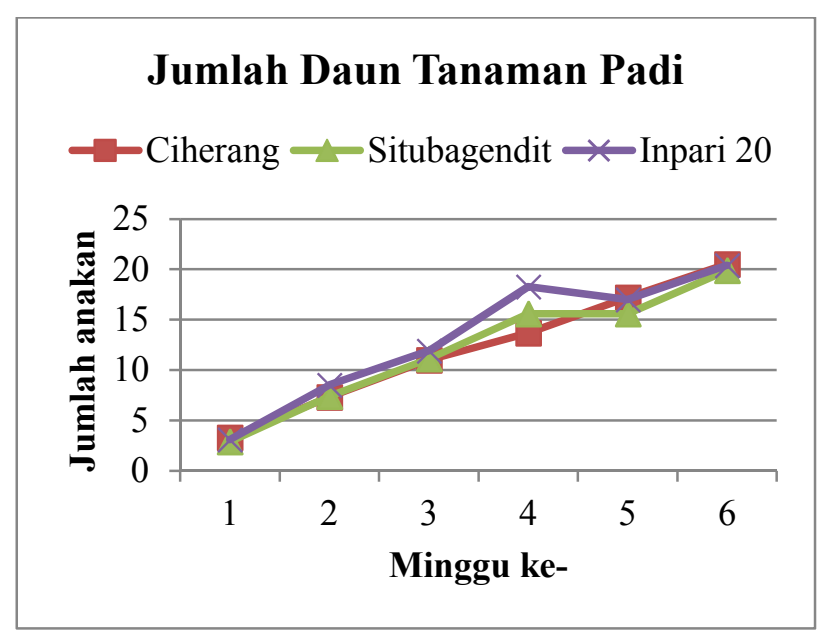

Gambar 2. Jumlah daun tiga varietas tanaman padi pada 6 minggu pertama setelah tanam

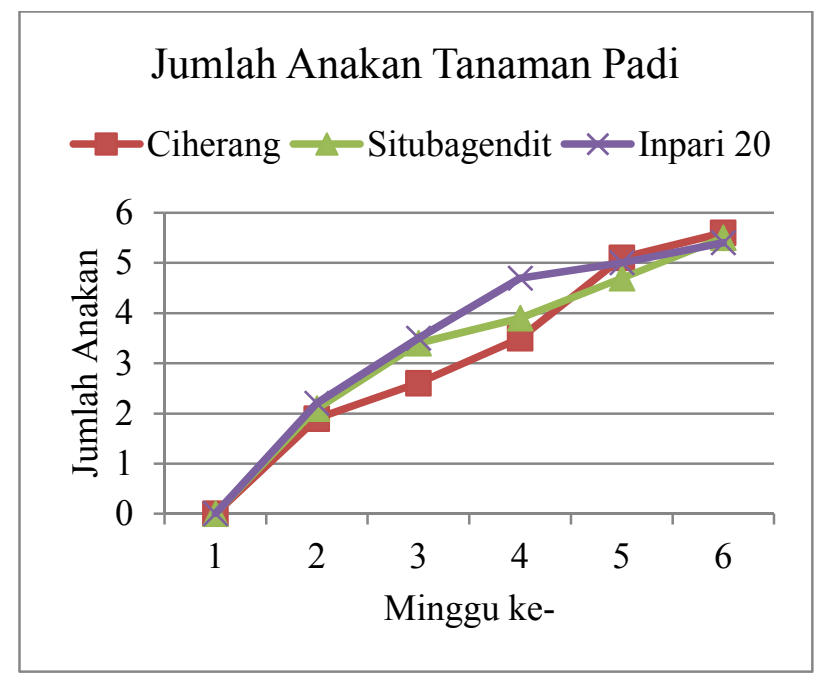

Gambar 3. Jumlah anakan tiga varietas tanaman padi pada 6 minggu pertama setelah tanam

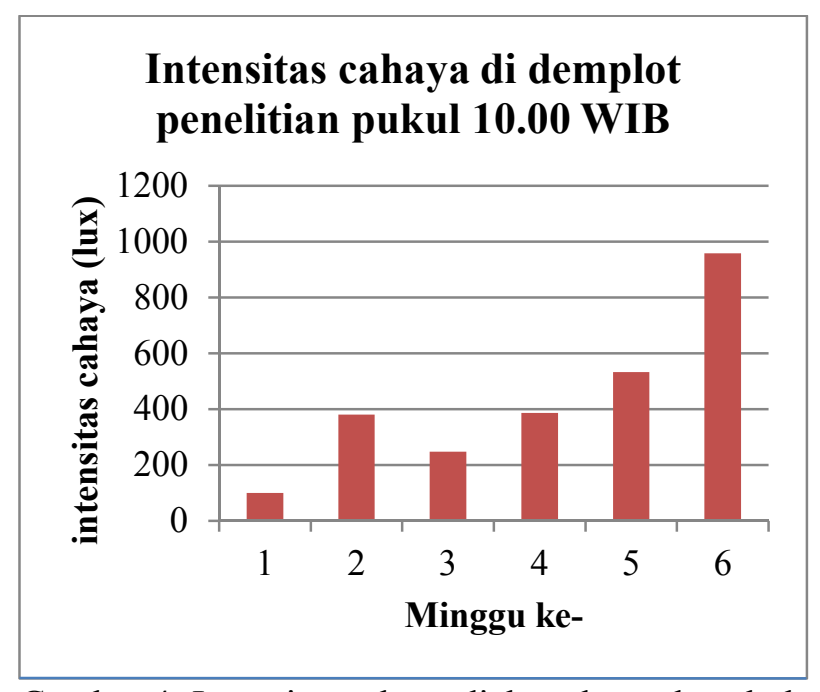

Gambar 4. Intensitas cahaya di demplot pada pukul $10.00 \mathrm{WIB}$

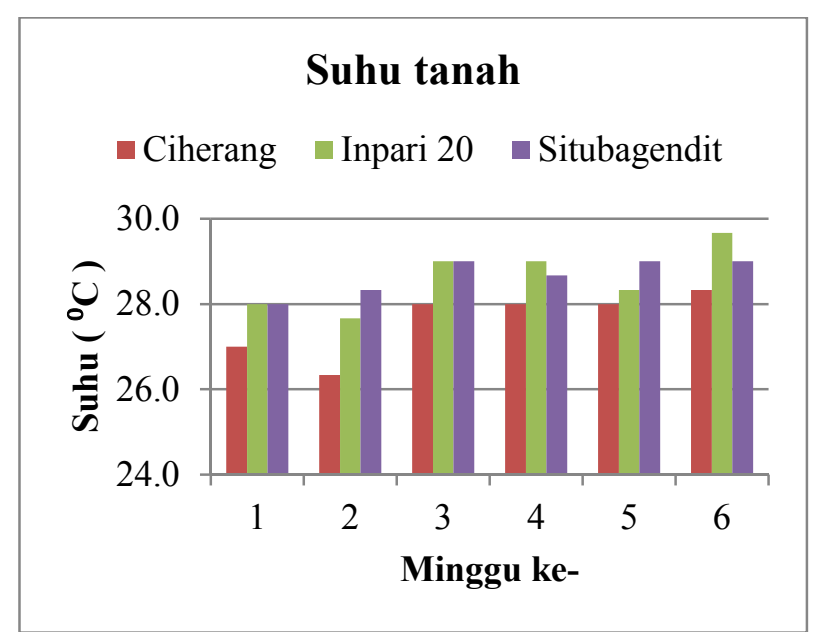

Gambar 5. Suhu tanah di area penanaman ketiga varietas tanaman padi 


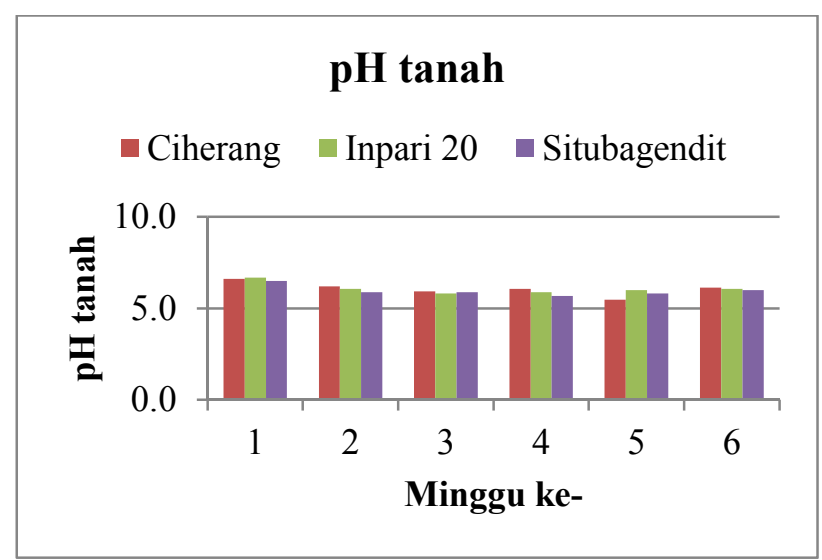

Gambar 6. pH tanah

Tabel 1. Hasil Analisis Tanah dengan dan tanpa pemberian pupuk bio cair

\begin{tabular}{cccc}
\hline Kode & $\begin{array}{c}\text { N tersedia } \\
(\mathrm{ppm})\end{array}$ & $\begin{array}{c}\text { P tersedia } \\
(\mathrm{ppm})\end{array}$ & $\begin{array}{c}\text { K tersedia } \\
(\mathrm{me} / 100 \mathrm{~g})\end{array}$ \\
\hline $\begin{array}{c}\text { Dengan } \\
\text { pupuk }\end{array}$ & 153,98 & 16,76 & 0,36 \\
\hline $\begin{array}{c}\text { Tanpa } \\
\text { pupuk }\end{array}$ & 134,84 & 9,37 & 0,16 \\
\hline
\end{tabular}

\section{PEMBAHASAN}

Berdasarkan data pertumbuhan ketiga varietas (Gambar 1, 2 dan 3) tanaman padi tumbuh dengan optimal. Tinggi tanaman ratarata telah mencapai $65 \mathrm{~cm}$ dengan jumlah daun 20 lembar serta anakan 5-6 anakan per lubang. Tanaman padi pada minggu ke-4 sampai sebelum minggu ke-7 aktif melakukan pembelahan untuk memproduksi anakan, setelah minggu ke-7 tanaman siap memasuki fase reproduktif dengan menginisiasi malai (Vergara, 1976). Munculnya daun baru yang berasal dari primordia daun, merupakan salah satu pertumbuhan tanaman padi.

Pada proses pertumbuhan, terjadi peningkatan massa dan volume serta jumlah sel secara irreversible. Pembentukan daun tanaman padi dimulai dengan re-orientasi sitoskeleton dan dinding sel primordia pucuk, sampai membentuk struktur primordia daun yang berbeda dari shoot apical meristem (SAM). Perkembangan selanjutnya, primordia daun membentuk struktur kuncup di sekitar SAM dan bagian mid-rib mulai membelah secara mitosis, ke arah apikal membentuk helaian daun, ke arah basal membentuk upih daun. Pertumbuhan ke arah apikal lebih dominan sehingga daun membentuk pita panjang (Smith dan Hake, 1992). Pertumbuhan dan perkembangan daun dipengaruhi oleh ketersediaan air, hormon dan hasil fotosintesis. Air berperan meningkatkan tekanan turgor sel sehingga mendorong membran plasma dan dinding sel untuk membentang dan memanjang. Selanjutnya protein expansin merombak dinding sel. Auksin bekerjasama dengan pektin, selulosa dan hemiselulosa membangun kembali dinding sel dan membran plasma dengan ukuran dan volume lebih besar dari semula ( Cosgrove, 2008). Saat tanaman padi berumur 6 minggu setelah tanam, pemupukan selesai tiga tahap dan masuk fase generatif.

Intensitas cahaya (Gambar 4.) pada saat pengukuran (pukul 10.00 WIB), mempunyai tren naik setiap minggunya, berkait dengan cuaca Daerah Istimewa Yogyakarta yang memanas pada awal-awal bulan November 2013 ini. Bila dikaitkan dengan tinggi tanaman, tampak pertumbuhan melambat pada minggu ke-5 dan ke-6. Intensitas matahari yang terlalu tinggi menyebabkan terjadinya fotorespirasi pada tanaman padi, sebagai ciri khas tanaman C3. Fotorespirasi ini merupakan mekanisme perlindungan terhadap terbakarnya sel oleh intensitas matahari, namun berefek pada pengurangan produktivitas, berupa biomassa.

Intensitas cahaya matahari yang mempunyai tren naik dibarengi dengan suhu tanah (Gambar 5). Suhu tanah tidak naik secara drastis karena masih adanya air yang menggenangi lahan sebagai counter terhadap panas matahari. Pada Gambar 5 tampak adanya kenaikkan suhu tanah pada lahan Inpari 20. Lahan varietas ini terdapat di tengah demplot sehingga tidak tertutupi oleh pepohonan yang ada di samping demplot.

Pada fase pertumbuhan, faktor ketersediaan air, cahaya, suhu, kelembaban, hormon dan hasil proses fotosintesis dominan pengaruhnya, sebab pada fase ini sel-sel meristem aktif melakukan pembelahan, pemanjangan dan pembentangan sedangkan sel-sel dewasa aktif melakukan diferensiasi. Proses pembelahan, pemanjangan dan 
pembentangan sel menghasilkan pertumbuhan, yaitu bertambahnya massa dan volume sel secara irreversible. Pada proses ini air berfungsi menaikkan turgiditas sel dan mengisi vakuola sel, sehingga sel membentang, mendorong membran plasma dan dinding sel. Dinding sel dirombak oleh protein expansin, sehingga sel membentang, kemudian sel melakukan sintesis komponen selulosa, pektin dan hemiselulosa dibantu oleh kinerja hormon auksin, untuk membangun kembali membran plasma dan dinding sel (Cosgrove, 2008).

Berbeda dengan intensitas cahaya matahari dan suhu tanah, $\mathrm{pH}$ tanah (Gambar 6) tampak tidak banyak berubah sepanjang 6 minggu pertama setelah masa tanam. $\mathrm{pH}$ tanah berkisar 5,5 -7 atau ada pada batas normal. pH tanah dipengaruhi oleh aktivitas metabolisme mikroba di sekitar pucuk akar (rhizosfer) dan aktivitas mikroba dari pupuk bio cair. Pada kadar air yang optimum, mikroba mampu tumbuh dan melakukan metabolisme, misalnya pada Streptococcus. Bakteri ini menghasilkan asam laktat, asam asetat dan $\mathrm{CO}_{2}$ ketika memecah glukosa pada jalur glikolisis (Saraswati dkk, 2004). Namun secara umum, kisaran $\mathrm{pH}$ dan kelembaban tanah media penelitian masih dapat ditolerir oleh ketiga varietas tanaman padi.

Mikroba disamping mendekomposisi senyawa organik tanah, juga menlakukan aktivitas penangkapan nitrogen dari udara, mengikat $\mathrm{P}$ dan $\mathrm{K}$ untuk mempermudah absorbsinya ke akar tanaman. Pem-fiksasi gas $\mathrm{N}_{2}$ ( non-simbotik) dari udara ke dalam tanah antara lain: Azotobacter, Azotomonas, Azotococcus, Beijerinckia, Derxia, Xanthobacter, methylobacter dan Azospirillum. Sedangkan bakteri simbiotik antara lain Rhizobium, Bradyrhyzobium dan Azorhyzobium. Bakteri pelarut fosfat juga terdapat dalam pupuk bio cair ini, bakteri ini mengubah senyawa kompleks menjadi bentuk ion maupun garam yang dapat diserap oleh akar (Aryanta, 2002).

Mikrobia yang terkandung dalam pupuk bio cair memberikan peran sebagai pengikat air. Mikroba menempati daerah diferensiasi pada akar, daerah ini hanya mampu mengabsorbsi air dalam jumlah kecil.
Keberadaan mikroba pada daerah diferensiasi akar, membantu penyerapan air dan hara bagi tanaman. Daerah perakaran yang optimal menyerap hara, selain bulu akar adalah daerah pemanjangan, maka adanya mikroba di daerah diferensiasi juga membantu penyerapan hara tanaman. Ketersediaan hara bagi tanaman ditunjukkan oleh hasil analisis tanah dengan dan tanpapemberian pupuk bio cair (Tabel 1). Hasil analisis menunjukkan terjadinya peningkatan $\mathrm{N}, \mathrm{P}$ dan $\mathrm{K}$ tersedia di tanah. Nitrogen tersedia mengalami peningkatan $14,2 \%$, Forfor tersedia meningkat $78 \%$ dan Kalium tersedia meningkat sampai $125 \%$ dari kondisi sebelum diberikan perlakuan pupuk organik cair.

\section{KESIMPULAN}

Berdasarkan hasil pengukuran parameter pertumbuhan dan parameter lingkungan serta pembahasan di atas, dapat disimpulkan bahwa ketiga varietas padi yaitu Situbagendit, Ciherang dan Inpari 20 mempunyai pertumbuhan yang optimal serta terjadi peningkatan kandungan hara tanah pada aplikasi pupuk bio cair 10liter/ha di lahan sawah yang terimbas erupsi Merapi 2010.

\section{UCAPAN TERIMAKASIH}

1. LPPM UGM yang telah mendanai penelitian ini.

2. Masyarakat Desa Wukirsari, khususnya Dukuh Sruni, Kecamatan Cangkringan, Sleman, DIY.

\section{DAFTAR PUSTAKA}

Any J, Widodo B, Ribut L, dan Hamidin. 2011. Kajian Kerusakan bangunan akibat Erupsi Gunung Merapi Tahun 2010 di Kabupaten Sleman. Yogyakarta: Jurusan Teknik Lingkungan FTsP UII, Pusat Studi Lingkungan Universitas Islam Indonesia. http://www. dppm.uii.ac.id. Diakses 25 Maret 2013.

Aryantha INP, Nganro NR, Sukrasno dan Nandina E. 2002. Pengembangan dan Penerapan Pupuk Mikroba dalam Sistem Pertanian Organik. Bandung: Pusat Penelitian Antar Universitas Ilmu Hayati LPPM-Institut Teknologi Bandung. 
Cosgrove DJ. 2008. Mechanism of Cell Enlargement-Wall Loosening Protein. New York: University and State Collage. Isroi. 2009. Pupuk Organik, Pupuk Hayati dan Pupuk Kimia. http://www.blog-Isroi.com. Diakses 4 April 2009.

Saraswati R, Prihatini T, dan Hastuti RD. 2004. Teknologi Pupuk Mikrobia Untuk Meningkatkan Efisiensi pemupukan dan Keberlanjutan Sistem Produksi Padi Sawah. Jakarta: Pusat Penelitian dan Pengembangan Tanah dan Agroklimat. BPPT. http://www.deptan.go.id. Diakses 30 Juli 2010.

Siswanti DW, Olgananda M, dan Widhianto T. 2010. Innovation Rice Cultivation with Bio Organic Fertilizer to Increase
Productivity of Three Rice Cultivars (Oryza sativa L.) in Rainfed Land Beji Village, Ngawen, Gunung Kidul, Yogyakarta, Indonesia. Proceeding ICBS. Yogyakarta: Faculty of Biology, Universitas Gadjah Mada.

Tim Redaksi. 2011. Lahan Pertanian Desa Wukirsari mengering Pasca Erupsi Merapi. http://www.tribunnews.com. Diakses 26 Maret 2013.

Tim Redaksi. 2013. Tanah Sleman Sudah Sakit. http://www.tribunnews.com. Diakses 20 Maret 2013.

Vergara SB. 1976. Physiological and Morphological Adaptability of Rice Varieties to Climates. Varieties and Climates. Philippines: IRRI. 